\title{
THE EFFECT OF NON-PERFORMING FINANCING AND THIRD PARTY FUNDS ON THE PROFITABILITY THROUGH PS/RS AND PLS FINANCING
}

\author{
Dr. Kautsar Riza Salman \\ Associate Professor \\ University of Hayam Wuruk, Indonesia \\ E-mail: kautsar@perbanas.ac.id
}

\begin{abstract}
This research is motivated by the phenomenon of increasing PS/RS and PLS financing and profitability at Islamic Commercial Banks (BUS) in Indonesia during the 2015-2019 period, and experiencing a decline from 2019 to 2020. PS/RS and PLS financing can use mudharabah and musharakah contract schemes. Mudharabah financing is based on profit sharing, while Musharaka is based on profit-loss sharing. This study aims to obtain empirical evidence regarding the effect of non-performing financing and third-party funds on profitability through PS/RS and PLS financing. The population used in this study were all Islamic Commercial Banks in Indonesia in the 2015-2020 period. The data analysis technique used is Partial Least Square with SmartPLS software version 3. The results of the study found a direct effect of non-performing financing on profitability. The results of the study did not find a direct effect of non-performing financing on $P S / R S$ and PLS financing. In addition, third party funds do not have a direct effect on profitsharing and profitability-based financing. The results also did not find an indirect effect of nonperforming financing and third-party funds on profitability.
\end{abstract}

Keywords: Non-Performing Financing, Profitability, PS/RS and PLS Financing, Third-Party Funds.

JEL Classification Codes: A19, B10, B25, C10, C53.

\section{INTRODUCTION}

Profit-sharing based financing such as mudarabah and musharakah financing is the main business carried out by Islamic banks, not buying and selling such as murabahah, salam, or istishna'. Mudharabah and musharakah contracts in Islamic banks were initially regulated in the accounting standards of PSAK 59 concerning Accounting for Islamic Banking. Currently, the implementation of mudharabah contracts in Indonesia is regulated in the accounting standards of PSAK 105 and Fatwa DSN 07/DSN-MUI/IV/2000, while musharakah is regulated in the accounting standards of PSAK 106 and Fatwa of DSN 08/DSN-MUI/IV/2000. In mudharabah financing, Islamic banks are the owner of the funds and the customer is the manager. As for musharakah financing, Islamic banks act as passive partners and customers as active partners, both of which contribute to capital (Salman, 2017; and Salman, 2020). In this study, we use terminology PS/RS and PLS financing. Profit sharing/Revenue sharing (PS/RS) is used by mudharabah contract, and Profit Loss Sharing (PLS) is used by musharakah contract. 
Profit-sharing or revenue-sharing received by Islamic banks from mudharabah and musharakah financing will also contribute to increasing the profitability of Islamic banks. This is supported by the trend of PS/RS and PLS financing and profitability data. Based on a study of the data in Indonesia on the amount of PS/RS and PLS financing, it is known that there is an interesting phenomenon that needs to be observed, namely the increase in PS/RS and PLS financing during the period 2016-2019 as shown in Figure 1. The average PS/RS and PLS financing is obtained from the average comparison between total PS/RS and PLS financing to total financing. There is an increase in PS/RS and PLS financing in Islamic Banks from 2015-2019. For 5 years (20152019), this ratio has increased in succession and decreased slightly in 2020. In addition, an average of $50 \%$ of the total financing provided by Islamic banks is allocated in the form of PS/RS and PLS financings such as mudharabah and musharakah.

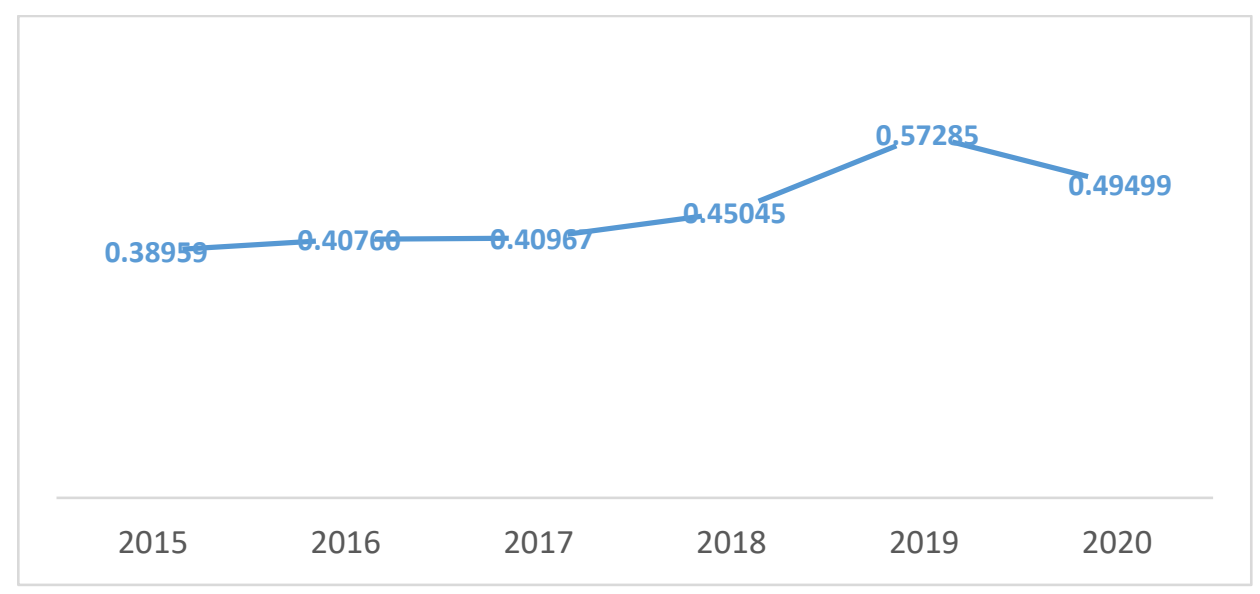

Figure 1. Profit Sharing Ratio for Islamic Commercial Banks (2015-2020)

The profitability of Islamic banks in Indonesia during the last 6 years (2015-2020) also tends to increase in line with the increase in PS/RS and PLS financing. The profitability ratio for a period of 4 (four) years (2015-2018) is negative, which means that Islamic commercial banks suffer losses. The lowest ROA occurred in 2015 at $-1.46 \%$ and continued to improve until 2019. In the last 2 (two) years (2019-2020), ROA showed a positive ratio indicating that the average was 1.64\% and $1.18 \%$ (Figure 2). Seeing two phenomenon, this study aims to examine whether the increase in profitability and PS/RS and PLS financing generated by Islamic commercial banks in Indonesia is caused by non-performing financing and third party fund.

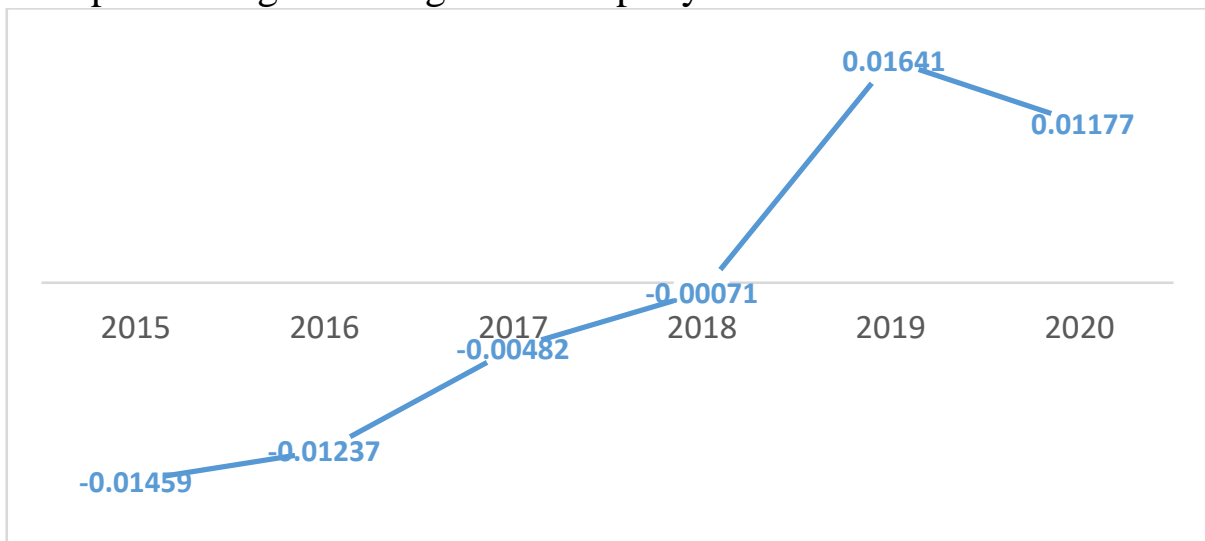

Figure 2. Profitability of Islamic Commercial Banks (2015-2020) 
One of the factors that are thought to affect the amount of PS/RS and PLS financing and profitability is non-performing financing (NPF). The better the management of Islamic banks for non-performing financing (substandard, doubtful, and loss) it can increase financing and the profitability of Islamic banks. Non-performing financing occurs because the customer as the manager is unable to return the business capital and pay for the results that are the rights of Islamic banks. The results of previous research showed contradictory results where Permataningayu and Mahdaria (2019), Al Arif and Nurhikmah (2017), Giannini (2013), and Wahab (2014) did not find the effect of NPF on PS/RS and PLS financing.

The empirical findings show contradictory results regarding the effect of NPF on profitability. Saras et al. (2020), Rizal and Rofiqo (2020), Kinanti and Purwohandoko (2017) and Rizal (2016) empirically found the effect of NPF on profitability, on the other hand, Sutrisno (2020), Wirman (2017) and Jatmiko et al. (2017) did not find the effect of NPF on profitability. All previous studies still use multiple linear regression analysis with SPSS, the current study tries to use a different analytical technique, namely partial least squares (PLS) involving a longer time period of 6 years (2015-2020). Interestingly, the impact of COVID-19 on Islamic banking worldwide, including in Indonesia, it has resulted in a decline in PS/RS and PLS financing and profitability performance from 2019 to 2020 . The results of previous studies did not analyze financial statement data in 2020 where since March 2020 there has been an epidemic of covid-19.

Third-party funds (TPF) are sources of funding received by Islamic banks from customers in the form of savings products, current accounts, and time deposits. In Islamic banks, savings can use a mudharabah or wadiah contract, demand deposits can use a mudharabah or wadiah contract, while deposits only use a mudharabah contract (Salman, 2017). Conceptually, the more TPF that Islamic banks have accumulated, the more the amount of financing disbursed and the profitability generated by Islamic banks. During the last 3 years (2018-2020) there was an increase in the growth of TPF, from -0.05668 in 2018 to 0.05891 in 2020. This was also followed by an increase in the PS/RS and PLS financing ratio from 0.45045 in in 2018 to 0.49499 in 2020. Similarly, ROA increased from -0.00071 in 2018 to 0.01177 in 2020 and ROE also increased from 0.02414 in 2018 to 0.04533 in 2020 .

Nevertheless, the results of empirical research show a research gap, where several studies have found the effect of TPF on the amount of PS/RS and PLS financing, such as Nurdiansyah, et al. (2020), Permataningayu and Mahdaria (2019), Al Arif and Nurhikmah (2017), Husaeni (2017), Sholikhah, et al. (2017), Amelia and Hardini (2017), and Wahyudi (2016), on the other hand, Darma \& Rita (2011) did not find the effect of TPF on PS/RS and PLS financing.

This study offers novelty in terms of models and analytical techniques used. The research model has never been used in previous research, where the current model examines the effect of NPF and TPF on profitability through PS/RS and PLS financing. This study uses partial least squares with SmartPLS version 3 software which is still relatively rarely used.

\section{The Effect of NPF on PS/RS and PLS Financing}

The ratio of NPF indicates the risk of financing in the categories of loss, doubt and substandard which has the potential to harm Islamic banks. The customer as a business manager (mudharib) is unable to pay the profit sharing that is the right of the Islamic bank and at the same time unable to return his capital to the Islamic bank (Salman, 2017; Salman, 2020). This has resulted in a decrease in the amount of financing that can be disbursed by Islamic banks, especially on PS/RS and PLS financings such as mudharabah and musharakah. Nevertheless, the results of empirical studies 
show different findings such as those of Permataningayu \& Mahdaria (2019), Al Arif and Nurhikmah (2017), Giannini (2013), and Wahab (2014).

\section{$H_{1}:$ NPF affects PS/RS and PLS financing}

\section{The Effect of NPF on Profitability}

Non-performing financing contributed to the decline in the profitability of Islamic banks. NPF in Islamic banks can occur in mudharabah and musharakah financing. Islamic banks act as owners of funds (shahibul maal), while customers as managers (mudharib). Managers who experience business bottlenecks are unable to pay the profit sharing that is the right of Islamic banks, as well as unable to pay the principal capital. This of course has an impact on decreasing the level of profitability. This concept is supported by empirical results conducted by Sarasi et al. (2020), Rizal and Rofiqo (2020), Kinanti and Purwohandoko (2017) and Rizal (2016) who found the effect of NPF on profitability. The higher the NPF ratio, the risk of NPF in Islamic banks will also increase. Increased problem financing, which means an increase in NPF can reduce bank performance and operations so that it can have an impact on decreasing profitability.

\section{$\mathrm{H}_{2}: \mathrm{NPF}$ affects profitability}

\section{The Effect of PS/RS and PLS Financing on Profitability}

PS/RS and PLS financing at Islamic banks refers to mudharabah financing and musharakah financing. In the financing contract, the Islamic bank obtains revenue sharing from the manager which can be calculated from gross profit or net profit depending on the agreement in the contract. Thus, conceptually, it can be explained that the greater the amount of profit-sharing disbursed by Islamic banks can have an impact on increasing the profitability of Islamic banks. Kinanti and Purwohandoko (2017) found the effect of financing on profitability.

\section{$H_{3}: P S / R S$ and PLS financing affects profitability}

\section{The Effect of TPF on PS/RS and PLS Financing}

TPF are funds that have been successfully collected by Islamic banks from customers with savings, current accounts and deposits using wadiah and mudharabah contracts. Wadiah means a deposit contract, while mudharabah is a business cooperation contract. In a fund-raising agreement with mudharabah, the Islamic bank is the business manager, while the customer is the owner of the funds. The increasing number of TPF that have been collected by Islamic banks has an impact on the increasing number of PS/RS and PLS financing distributed by Islamic banks to business management customers. This concept is strengthened by the results of empirical research that finds a positive effect of TPF on the amount of PS/RS and PLS financing, as found by Nurdiansyah, et al. (2020), Al Arif and Nurhikmah (2017), Husaeni (2017), Sholikhah, et al. (2017), Amelia and Hardini (2017), and Wahyudi (2016).

\section{H4: TPF affects PS/RS and PLS financing}

\section{The Effect of TPF on Profitability}

TPF in the context of Islamic banks refer to public funds that have been successfully collected by Islamic banks through demand deposits, savings and time deposits, both under wadiah contracts 
and mudharabah contracts. These third-party funds will then be channelled by Islamic banks to various types of financing, both sale and purchase financing and PS/RS and PLS financing. Conceptually it can be said that the greater the TPF that have been collected by Islamic banks can increase the profitability of Islamic banks due to the increase in margin income, fees and profitsharing obtained by Islamic banks. Rizal and Rofiqo (2020), Diana and Huda (2019), Hermuningsih (2019) and Kinanti and Purwohandoko (2017) found the influence of TPF on the profitability of Islamic banks.

\section{$H_{5}:$ TPF affects profitability}

\section{Definition and Measurement of Variables}

\section{METHOD}

The exogenous variables used are non-performing financing and third-party funds, while the endogenous variables used are profit sharing-based financing and profitability. Non-performing financing is financing that is included in the substandard, doubtful, and loss categories. The term non-performing loans (NPL) is for commercial banks, while non-performing financing (NPF) is for Islamic banks. Non-performing financing variables are measured by NPF Gross and NPF Net. Third-party funds are funds obtained from the public, both individuals and business entities, in rupiah and foreign currencies, using various deposit product instruments owned by Islamic banks which include: wadiah savings, wadiah demand deposits, mudharabah savings, mudharabah current accounts, and mudharabah deposits. This variable is measured by the growth of TPF.

PS/RS and PLS financing uses mudharabah and musharakah contracts. Mudharabah is a business cooperation agreement between the owner of the funds (Islamic bank) and the business manager (mudharib) to carry out business activities, profits are divided on the basis of profitsharing ratio according to the agreement of both parties, whereas if there is a loss, it will be borne by the owner of the funds unless caused by misconduct., negligence, and violation by fund managers (Salman, 2017). The Musharakah is a cooperation agreement between two or more parties for a particular business, in which each party contributes funds provided that profits are divided based on an agreement while losses are based on the portion of the contribution of funds (DSN Fatwa and PSAK 106). This variable indicator refers to Al Arif and Nurhikmah (2017), namely the comparison between PS/RS and PLS financing and total financing.

Profitability in the study is defined as a measure that shows the extent to which Islamic banks generate profits as a result of the company's operations. Profitability is measured by return on assets (ROA). ROA in this study refers to Umiyati and Syarif (2016) measured by the comparison between profit before tax with average total assets in a period.

\section{Population and Sample}

This study used all Islamic commercial banks in Indonesia as population in the 2015-2020 period. The sampling method used purposive, with the following criteria: (1) publication of financial statements and annual reports for the 2015-2020 period; and (2) available research data related to the measurement of all research variables.

\section{Partial Least Square Analysis with Smart PLS version 3}

In Partial Least Square, the outer model and inner model are assessed. Testing the outer model is done by looking at convergent validity, discriminant validity, and composite reliability. The inner model test was carried out using bootstrapping to assess the significance of the path coefficients, assessing f square, R square, and model fit (Hair et al., 2011). 


\section{Convergent Validity}

\section{RESULTS}

A convergent validity test is done by looking at the outer loading value of each indicator. The test after eliminating indicators shows that all indicators have outer loading > 0.7 (Table 1).

Table 1. Convergent Validity

\begin{tabular}{|l|r|r|r|r|}
\hline & $\begin{array}{c}\text { Non Performing } \\
\text { Financing }\end{array}$ & $\begin{array}{c}\text { PS/RS and } \\
\text { PLS Financing }\end{array}$ & Profitability & $\begin{array}{c}\text { Third Party } \\
\text { Fund }\end{array}$ \\
\hline $\mathrm{X}_{1.1}$ & 0,930 & & & \\
\hline $\mathrm{X}_{1.2}$ & 0,816 & & & 1,000 \\
\hline $\mathrm{X}_{2.1}$ & & & & \\
\hline $\mathrm{Y}_{1.2}$ & & 1,000 & & \\
\hline $\mathrm{Y}_{2.1}$ & & & 0,943 & \\
\hline $\mathrm{Y}_{2.2}$ & & & 0,925 & \\
\hline
\end{tabular}

\section{Discriminant Validity}

This test uses the Fornell-Larcker criterion. Each indicator must be highly correlated with its construct compared to the cross-loading of the indicator with other constructs. The Fornell-Larcker Criterion results show that the loading of each variable is greater than its cross loading (Table 2).

Table 2. Discriminant Validity

\begin{tabular}{|l|r|r|r|r|}
\hline & $\begin{array}{c}\text { Non Performing } \\
\text { Financing }\end{array}$ & $\begin{array}{c}\text { PS/RS and } \\
\text { PLS Financing }\end{array}$ & Profitability & $\begin{array}{c}\text { Third } \\
\text { Party } \\
\text { Fund }\end{array}$ \\
\hline $\begin{array}{l}\text { Non Performing } \\
\text { Financing }\end{array}$ & 0,875 & & & \\
\hline Profit-Based Financing & 0,326 & 1,000 & & \\
\hline Profitability & $-0,716$ & $-0,298$ & 0,934 & \\
\hline Third Party Fund & $-0,289$ & $-0,325$ & 0,083 & 1,000 \\
\hline
\end{tabular}

\section{Construct Reliability}

The construct reliability test was carried out by looking at Cronbach's alpha, rho_A, and composite reliability values, as well as AVE. The results of the reliability test showed that all variables had a value $>0.70$ (Table 3$)$.

Table 3. Construct Reliability

\begin{tabular}{|l|r|r|r|r|}
\hline & Cronbach's Alpha & \multicolumn{1}{|c|}{ rho_A } & $\begin{array}{c}\text { Composite } \\
\text { Reliability }\end{array}$ & $\begin{array}{c}\text { Average } \\
\text { Variance } \\
\text { Extracted } \\
\text { (AVE) }\end{array}$ \\
\hline Non Performing Financing & 0,706 & 0,805 & 0,866 & 0,765 \\
\hline PS/RS and PLS Financing & 1,000 & 1,000 & 1,000 & 1,000 \\
\hline
\end{tabular}




\begin{tabular}{|l|r|r|r|r|}
\hline Profitability & 0,854 & 0,865 & 0,932 & 0,872 \\
\hline Third Party Fund & 1,000 & 1,000 & 1,000 & 1,000 \\
\hline
\end{tabular}

\section{f Square}

There is one variable that has a large effect, namely non-performing financing with a value $>0.35$, which is 0.982 , none of which has a moderate effect because the value of $f$ square $<0.15$. The other independent variables have a small effect with a score $>0.02$ (Table 4).

Table 4. f Square

\begin{tabular}{|l|r|r|r|r|}
\hline & $\begin{array}{c}\text { Non Performing } \\
\text { Financing }\end{array}$ & $\begin{array}{c}\text { PS/RS and } \\
\text { PLS Financing }\end{array}$ & Profitability & $\begin{array}{c}\text { Third Party } \\
\text { Fund }\end{array}$ \\
\hline $\begin{array}{l}\text { Non Performing } \\
\text { Financing }\end{array}$ & & 0,070 & 0,982 & \\
\hline $\begin{array}{l}\text { Profit-Based } \\
\text { Financing }\end{array}$ & & & 0,024 & \\
\hline Third Party Fund & & 0,070 & 0,050 & \\
\hline
\end{tabular}

\section{R Square and R Adjusted Square}

The model with endogenous profitability was a moderate model because it had R Square and $\mathrm{R}$ Square Adjusted $>50 \%$ by $54.1 \%$ and $51.8 \%$, respectively (Table 5).

Table 5. $R$ square

\begin{tabular}{|l|r|r|}
\hline & R Square & R Square Adjusted \\
\hline $\begin{array}{l}\text { PS/RS and PLS } \\
\text { Financing }\end{array}$ & 0,164 & 0,138 \\
\hline Profitability & 0,541 & 0,518 \\
\hline
\end{tabular}

\section{Model Fit}

The research model does not meet the model fit criteria where RMS Theta $>0.102$ is 0.401 (Table 7) and the NFI value $<0.9$ is 0.679 (Table 6). Based on these two assessments, the model does not meet the fit criteria so it is necessary to look at the SRMR value. The SRMR value in the saturated model and estimated model $<0.1$ is 0.075 (Table 6) so model fits the data.

Table 6. Model Fit

\begin{tabular}{|l|r|r|}
\hline & Saturated Model & \multicolumn{1}{|c|}{ Estimated Model } \\
\hline SRMR & 0,075 & 0,075 \\
\hline d_ULS & 0,117 & 0,117 \\
\hline d_G & 0,117 & 0,117 \\
\hline Chi-Square & 50,879 & 50,879 \\
\hline NFI & 0,679 & 0,679 \\
\hline
\end{tabular}


Table 7. RMS Theta

rms Theta

0,401

\section{Direct Effect}

The path coefficient which is the output of the bootstrapping analysis in the form of a direct effect shows a significant direct effect of NPF on profitability. The direct effect of NPF on PS/RS and PLS financing is not significant. In addition, the direct effect of NPF, PS/RS and PLS financing, and third-party funds is not significant on profitability (Table 8).

Table 8. Path Coefficient

\begin{tabular}{|l|r|r|r|r|r|}
\hline & $\begin{array}{c}\text { Original Sample } \\
\text { (O) }\end{array}$ & $\begin{array}{c}\text { Sample Mean } \\
\text { (M) }\end{array}$ & $\begin{array}{c}\text { Standard } \\
\text { Deviation } \\
(\text { STDEV })\end{array}$ & $\begin{array}{c}\text { T Statistics } \\
(\mid \mathrm{O} / \text { STE } \\
\text { V|) }\end{array}$ & $\begin{array}{c}\text { P } \\
\text { Values }\end{array}$ \\
\hline $\begin{array}{l}\text { Non Performing } \\
\text { Financing -> } \\
\text { PS/RS and PLS } \\
\text { Financing }\end{array}$ & 0,253 & 0,250 & 0,148 & 1,711 & 0,088 \\
\hline $\begin{array}{l}\text { Non Performing } \\
\text { Financing -> } \\
\text { Profitability }\end{array}$ & $-0,726$ & $-0,742$ & 0,081 & 9,000 & 0,000 \\
\hline $\begin{array}{l}\text { Profit-Based } \\
\text { Financing -> } \\
\text { Profitability }\end{array}$ & $-0,115$ & $-0,143$ & 0,105 & 1,096 & 0,274 \\
\hline $\begin{array}{l}\text { Third Party Fund } \\
->\text { PS/RS and PLS } \\
\text { Financing }\end{array}$ & $-0,252$ & $-0,242$ & 0,161 & 1,567 & 0,118 \\
\hline $\begin{array}{l}\text { Third Party Fund } \\
->\text { Profitability }\end{array}$ & $-0,164$ & $-0,165$ & 0,194 & 0,846 & 0,398 \\
\hline
\end{tabular}

\section{Indirect Effects}

The output of the bootstrapping analysis in the form of an indirect effect shows that the indirect effect of NPF and TPF is not significant on profitability (Table 9).

Table 9. Indirect Effect

\begin{tabular}{|l|r|r|r|r|r|}
\hline & $\begin{array}{c}\text { Original Sample } \\
(\mathrm{O})\end{array}$ & $\begin{array}{c}\text { Sample Mean } \\
(\mathrm{M})\end{array}$ & $\begin{array}{c}\text { Standard } \\
\text { Deviation } \\
(\text { STDEV })\end{array}$ & $\begin{array}{c}\text { T Statistics } \\
(\mid \text { O/STDEV|) }\end{array}$ & $\begin{array}{c}\text { P } \\
\text { Values }\end{array}$ \\
\hline $\begin{array}{l}\text { Non Performing } \\
\text { Financing -> } \\
\text { Profitability }\end{array}$ & $-0,029$ & $-0,032$ & 0,032 & 0,901 & 0,368 \\
\hline $\begin{array}{l}\text { Third Party Fund } \\
->\text { Profitability }\end{array}$ & 0,029 & 0,031 & 0,037 & 0,789 & 0,430 \\
\hline
\end{tabular}




\section{Total Effect}

The output results show that NPF has a significant total effect on profitability because it has a pvalue $<0.05$, which is 0.000 , while the other total effect is not significant because of p-value $>$ 0.05 (Table 10).

Table 10. Total Effect

\begin{tabular}{|l|r|r|r|r|r|}
\hline & $\begin{array}{c}\text { Original } \\
\text { Sample (O) }\end{array}$ & $\begin{array}{c}\text { Sample } \\
\text { Mean (M) }\end{array}$ & $\begin{array}{c}\text { Standard } \\
\text { Deviation } \\
\text { (STDEV) }\end{array}$ & $\begin{array}{c}\text { T Statistics } \\
(|\mathrm{O} / \mathrm{STDEV}|)\end{array}$ & $\begin{array}{c}\text { P } \\
\text { Values }\end{array}$ \\
\hline $\begin{array}{l}\text { Non Performing Financing - } \\
>\text { PS/RS and PLS Financing }\end{array}$ & 0,253 & 0,250 & 0,148 & 1,711 & 0,088 \\
\hline $\begin{array}{l}\text { Non Performing Financing - } \\
>\text { Profitability }\end{array}$ & $-0,755$ & $-0,774$ & 0,081 & 9,336 & 0,000 \\
\hline $\begin{array}{l}\text { Profit-Based Financing -> } \\
\text { Profitability }\end{array}$ & $-0,115$ & $-0,143$ & 0,105 & 1,096 & 0,274 \\
\hline $\begin{array}{l}\text { Third Party Fund -> PS/RS } \\
\text { and PLS Financing }\end{array}$ & $-0,252$ & $-0,242$ & 0,161 & 1,567 & 0,118 \\
\hline $\begin{array}{l}\text { Third Party Fund -> } \\
\text { Profitability }\end{array}$ & $-0,135$ & $-0,134$ & 0,178 & 0,756 & 0,450 \\
\hline
\end{tabular}

\section{The effect of NPF on PS/RS and PLS financing}

\section{DISCUSSION}

The results of the study prove empirically that NPF has a positive direction but does not significantly affect PS/RS and PLS financing. The results of this study are supported by data trends during the research period (2015-2020) which show that the number of non-performing financing both measured by Gross NPF and Net NPF in Islamic banks has decreased while profit sharingbased financing for the last 4 years (2017-2020) has also experienced a decline. The condition illustrates that the good of Islamic banks in managing non-performing financing, which is characterized by a low NPF, does not necessarily have a positive impact in increasing the financing ratio in Islamic banks and even causes the financing ratio to decrease.

The findings show that NPF has no significant effect on PS/RS and PLS financing. Thus the positive direction resulting from the relationship between the two variables is ignored. Gross NPF data shows that although there has been a decline over the last 3 years, the decline is not significant so that Islamic banks do not make the basis for consideration in increasing the amount of PS/RS and PLS financing. Even from 2015 to 2016, Gross NPF experienced a significant increase based on the Gross NPF trend for the last 6 years. In addition, the findings of this study also support the results of previous research conducted by Permataningayu and Mahdaria (2019), Al Arif and Nurhikmah (2017), Giannini (2013), and Wahab (2014) which also did not find a significant effect of NPF on PS/RS and PLS financing.

\section{The effect of NPF on profitability}

In this finding, NPF was proven to have a significant and negative effect on profitability. NPF trend data shows that during the research period (2015-2020) Islamic banks are able to manage the amount of NPF well as evidenced by the declining trend. Even though the 2015-2018 period ROA was negative, the trend during that period was getting better and the last 2 years (2019-2020) 
showed the ROA ratio was positive. This means that the declining number of non-performing financing contributed to the increasing ROA ratio in Islamic banks during this period.

The declining trend of NPF as indicated by the declining Gross NPF and Net NPF ratios contributed significantly to the ROE ratio in Islamic banks. This is indicated by the better ROE ratio for the last 3 (2018-2020) which shows a positive number after the previous period suffered losses. These results are in line with and support the results of previous studies such as those of Sarasi et al. (2020), Rizal and Rofiqo (2020), Kinanti and Purwohandoko (2017) and Rizal (2016) empirically found the effect of NPF on profitability.

\section{The effect of PS/RS and PLS financing on profitability}

The results of the study did not find the effect of PS/RS and PLS financing (mudharabah and musharakah) on the profitability of Islamic banks. The direction of the relationship is negative and insignificant. This finding is supported by data trends which show that a decrease in FDR over the last 6 years has resulted in an increase in ROA and ROE, but the effect is not significant. This could be due to an increase in FDR from 2015 to 2016 from $94.17 \%$ to $94.54 \%$, and during the last 4 years, it has continued to decline. This condition resulted in the insignificant effect of FDR in Islamic banks on their profitability during the last 6 periods (2015-2020). The findings support previous studies conducted by Rizal and Rofiqo (2020) and Diana and Huda (2019) which did not find the effect of PS/RS and PLS financing on profitability.

\section{The effect of TPF on PS/RS and PLS financing}

The direction of the negative relationship between TPF and PS/RS and PLS financing, meaning that the increasing TPF received by Islamic banks from the public, both those received in the form of savings (wadiah and mudharabah), demand deposits (wadiah and mudharabah), and mudharabah deposits resulted in a decrease in the amount PS/RS and PLS financing with mudharabah and musharakah schemes.

The results of the study show that there is a negative direction of the relationship between TPF and PS/RS and PLS financing which is also supported by data trends during the research period (2015-2020). Although there was a decrease in TPF in 2018 compared to TPF in the previous year (2017), during the last 2 years (2019-2020) the growth of TPF experienced a significant increase. However, the average increase in the growth of TPF during the study period did not significantly reduce the amount of PS/RS and PLS financing. The increase in TPF has resulted in Islamic banks tending to allocate their funds more to financing with less risk and more certain contracts such as murabahah and ijarah, where Islamic banks will receive fixed returns such as margins in murabahah and fees in ijarah or rental of goods benefits. or services. This indicates the influence of TPF that do not significantly affect PS/RS and PLS financing. The results of this study support the study of Darma and Rita (2011) which did not find the effect of TPF on PS/RS and PLS financing.

\section{The effect of TPF on profitability}

The results of the study did not find the effect of TPF on the profitability of Islamic banks. The direction of the relationship is negative, meaning that the increasing number of TPF that can be collected by Islamic banks causes the profitability of Islamic banks to tend to decrease. The direction of this relationship is in accordance with the trend of the data between the two, where the trend of third party funds during the study period (2015-2020) tends to decrease, especially in the 2015-2018 period although it has increased from 2019 to 2020. On the contrary, the trend of ROA 
and ROE tends to rise even though the average profitability of Islamic banks in the 2015-2018 period has a negative ROA. Likewise, the worst ROE ratio occurred in 2017 at $-10.8 \%$. This condition causes TPF to not have a significant impact on increasing or decreasing profitability ratios.

\section{CONCLUSION AND SUGGESTION}

This study examines the effect of NPF and TPF on PS/RS and PLS financing. In addition, the study also examines the effect of NPF, PS/RS and PLS financing and TPF on profitability. The results showed that NPF and TPF were not empirically proven to affect PS/RS and PLS financing.

The results of the study found that NPF was empirically proven to affect the profitability of Islamic banks in a negative direction. The lower the NPF in Islamic banks, the higher the level of profitability obtained by Islamic banks. This study also shows the results that PS/RS and PLS financing and TPF are not empirically proven to affect the profitability of Islamic banks. The results of the indirect effect also show the finding that NPF is not empirically proven to have an indirect effect on profitability. Similarly, TPF are also not empirically proven to have an indirect effect on profitability.

This research suggestion is intended for Islamic banks and for future researchers. Islamic banks should pay attention to the management of the amount of NPF because good management of NPF can increase the profitability of Islamic banks. For further researchers, other independent variables can be added, such as profit sharing on deposits, capital adequacy ratios, and operational efficiency ratios.

\section{REFERENCES}

Al Arif, M. N. R., \& Nurhikmah, I. (2017). Determinan Pembiayaan Bagi Hasil Perbankan Syariah di Indonesia. Al-Falah: Journal of Islamic Economics, 2(1), 1-12.

Amelia, E., \& Hardini, E. F. (2017). Determinant of Mudharabah Financing: A Study at Indonesian Islamic Rural Banking. Etikonomi, 16(1), 43-52.

Darma, E. S., \& Rita, R. (2011). Faktor-Faktor Yang Berpengaruh terhadap Tingkat Pengguliran Dana Bank Syariah. Journal of Accounting and Investment, 12(1), 72-87.

Diana, N., \& Huda, S. (2019). Dana Pihak Ketiga dan Pendapatan Pembiayaan Bagi Hasil Terhadap Laba Pada Bank Umum Syariah Indonesia. Jurnal Akuntansi: Kajian Ilmiah Akuntansi, 6(1), 99-113.

Giannini, N. G. (2013). Faktor yang mempengaruhi pembiayaan Mudharabah pada bank umum syariah di Indonesia. Accounting Analysis Journal, 2(1).

Hair, J. F., Ringle, C. M., \& Sarstedt, M. (2011). PLS-SEM: Indeed a Silver Bullet. Journal of Marketing Theory and Practice, 19(2), 139-151. https://doi.org/10.2753/MTP10696679190202.

Husaeni, U. A. (2017). Determinan Pembiayaan Pada Bank Pembiayaan Rakyat Syariah di Indonesia. Esensi: Jurnal Bisnis dan Manajemen, 7(1), 49-62. https://doi.org/10.15408/ess.v7i1.4542. 
Hermuningsih, S. (2019). Third Party Funds and Indonesia's Sharia Banking Profitability with Revenue Sharing as Intervening Variable. East African Scholars Journal of Economics, Business and Management, 2(4), 242-251.

Jatmiko, U., Srikalimah \& Fitriyanto, D. (2017). Effect of Capital Adequacy Ratio and Non Performing Financing on Return on Asset In PT. Bank Rakyat Indonesia (BRI) Syariah Period 2012-2016. International Journal of Social Science and Business, 1(4), 222-228. http://dx.doi.org/10.23887/ijssb.v1i4.12038.

Kinanti, R. A. \& Purwohandoko, P. (2017). Influence of Third-Party Funds, CAR, NPF, and FDR towards the Return on Assets of Islamic Banks in Indonesia. Jurnal Ilmiah Bidang Akuntansi dan Manajemen (JEMA), 14(2), 135-143. http://dx.doi.org/10.31106/jema.v14i02.524.

Nurdiansyah, D. H., Ruchjana, E. T., \& Fahrunnisa, S. (2020). The Influence of Third Party Funds and Profit Sharing Rate on Profit Sharing Funding. Jurnal Riset Akuntansi, 10(1), 1-10. https://doi.org/10.36733/juara.v10i1.747.

Rizal, F. (2016). Pengaruh Capital Adequacy Ratio, Non Performing Finance dan Operational Efficiency Ratio Terhadap Profitabilitas Bank Pembiayaan Rakyat Syariah. Muslim Heritage, 1(1), 179-196. https://doi.org/10.21154/muslimheritage.v1i1.501

Rizal, F., \& Rofiqo, A. (2020). Determinants of Sharia Banking Profitability: Empirical Studies in Indonesia 2011-2020. el Barka: Journal of Islamic Economic and Business, 3(1), 137-161.

Salman, K. R. (2017). Akuntansi Perbankan Syariah Berbasis PSAK Syariah. Jakarta: Penerbit Indeks.

Salman, K. R. (2020). Akuntansi Syariah: Pendekatan Akad dan Wa'd. Depok: Penerbit Rajawali Pers.

Sarasi, V., Helmi, A., \& Lisdiyanti, M. N. (2020). Pengaruh Pembiayaan Jual Beli, Bagi Hasil, Sewa-Menyewa Dan Non Performing Financing Terhadap Profitabilitas Bank Umum Syariah Di Indonesia Periode 2016-2018. Jurnal Ekonomi dan Bisnis Islam, 10(2), 1-10.

Sholikhah, Z., Pramuka, B. A., \& Adawiyah, W. R. (2017). Determinant of Equity Based Financing Volume: A Case of Islamic Banks in Indonesia. Research Journal of Finance and Accounting, 8(1), 30-39.

Sutrisno, S. (2020). Islamic Banks's Risks and Profitability A Case Study on Islamic Banks in Indonesia. Kinerja, 24(1), 57-65.

Umiyati, U., \& Syarif, S. M. (2016). Kinerja Keuangan dan Tingkat Bagi Hasil Deposito Mudharabah Pada Bank Umum Syariah Di Indonesia. Jurnal Akuntansi dan Keuangan Islam, 4(1), 45- 66. 
Wahab, W. (2014). Analisis Pengaruh FDR, NPF, Tingkat Bagi Hasil, Kualitas Jasa, dan Atribut Produk Islam Terhadap Tingkat Pembiayaan Mudharabah Pada Bank Umum Syariah di Semarang. Economica, 5(2), 107-136.

Wahyudi, A. (2016). Determinan Pembiayaan Murabahah Pada Unit Usaha Syariah: Model Regresi Panel. Esensi: Jurnal Bisnis dan Manajemen, 6(2), 227-236.

Wirman, W. (2017). Analisis Pembiayaan Berbasis Bagi Hasil dan Rasio BOPO pada Perbankan Syariah di Indonesia. Accounthink: Journal of Accounting and Finance, 2(2), 377-388.

\section{Copyrights}

Copyright for this article is retained by the author(s), with first publication rights granted to the journal. This is an open-access article distributed under the terms and conditions of the Creative Commons Attribution license (http://creativecommons.org/licenses/by/4.0). 